\title{
The Implementation of IT- Based Teaching Media to Teaching Media to Teach Skill in Reading Javanese Alphabets
}

\author{
Rochimansyah $^{1}$, Yuli Widiyono ${ }^{2}$, Menik Widiyati $^{3}$, Sutopo $^{4}$ \\ rochimansyah0@gmail.com \\ Universitas Muhammadiyah Purworejo
}

\begin{abstract}
This research aimed at investigating the students' skill on reading Javanese alphabets using IT-based teaching media at MAN (State Islamic High School) Kutowinangun. This was a quasi experimental research. The data analysis used t-test. The finding was the average score of reading skill in control group was 73.50. Meanwhile the average score of experimental group was 82.00. Hypothesis testing used t-test. Tcount was 4.359 and ttable was 1.670 . The conclusion drawn from the research was IT-based interactive teaching media can improve students' skill in reading Javanese alphabets.
\end{abstract}

Keywords: media, reading, information and technology

\section{Introduction}

As written on article 3 of Act No. 20, government tries to stimulate the notion of Javanese language teaching to reach national education goals. The goals emphasizes on developing students' comprehensive, kinesthetic, emotional, spritual, and intellectual intelligence so as education can do its role to shape dignified national characters and civilization in an attempt to educate the nation. Javanese is a regional language owned by people in Central Java, Special Region of Yogyakarta, and East Java. One of the ways to preserve, sustain, and develop regional languages formally is by inserting them to national curriculum and teaching them at schools.

Regional language particularly Javanese serves as a medium to communicate by people both in Java island and other areas across Indonesia, even in Suriname (Sudaryanto, 1992: 3)[1]. Javanese as a regional language is taught in Central Java province, East Java province, and Special Region of Yogyakarta province. Javanese is one of the compulsory local subjects at Elementary School and High Schools. Generally, language skills consist of four aspects: listening, speaking, reading, and writing (Tarigan, 2008:1)[2]. These apects are integrated and inseparable. This happens if they are taught consecutively. First of all is listening, then it is followed by speaking and then reading. The last one is writing.

The basic competence of Javanese subject is different from that of Indonesian subject. In Javanese subject, students have to master two skills at the same time namely reading Javanese texts with Latin alphabets and reading Javanese texts with Javanese alphabets. To be able to read Javanese texts with 
Javanese alphabets students have to understand Javanese language and Javanese alphabets. An observation done by the researchers toward Javanese teacher and eleventh grade students of MAN Kutowinagun showed that the basic competence of reading and comprehending texts with Javanese alphabets was not maximum yet.

As seen from the condition above, it is obvious that in teaching system at school, teachers have great responsibility to guide students in learning Javanese, particularly Javanese aphabets. In carrying out teacher-student interaction process, teachers have to play their role as teaching agents where teachers serve as facilitators and mediators. As facilitators in teaching-learning process, teachers make an effort to empower students so that they can develop themselves. Meanwhile, as mediators, teachers are obliged to have knowledge and sufficient understanding about teaching media.

Teaching media are communication tools to gain effective teaching-learning process. Media are one of the aids to reach particular goals or desired results. The choice should be adjusted to the subject and the goals. Thus, teaching media are indispensable to complete and to support the success of teaching-learning process at school. Teachers' creativity is required in teaching-learning process. For example they can make use of teaching media in the classroom.

The use of teaching media, as an effort to improve education quality, is essential in teachinglearning process. It will make the teaching-learning process better which in turn can improve the learning outcomes (Arsyad,2013)[3]. There are several reasons why teaching media can boost students' learning outcomes. First, they can attract students' attention to learn Javanese aphabets, so students' learning motivation will grow. Second, teaching materials are clearer, so students find it easier to understand. This also enables students to master teaching goals better. Third, teaching methods will vary. Teaching activity is not merely verbal communication which makes students bored. Students do more activities. Besides listening to teacher's explanation, they can observe, take notes, practice, demonstrate and ask questions to teacher (Trianto,2010)[4].

There are some kinds of teaching media commonly used in teaching-learning process (Oemar Hamalik,1985)[5]. They can be simulator, model/realia, flowchart, images, photos, tables, diagrams, graphic media, interactive media, projection media, etc (Arsyad,2013)[3]. At present, the sophistication and the progress of technology can be applied in the education domain. Innovation is necessary to create qualified teaching apps.

The development of technology enables us to get or to share information in communication process. Information and technology (IT) as well communication are wares designed to enable, help and process information. Ralph Stair (2011: 10)[6] states that the component in information and technology is computer-based information system. This system is a set of hardwares, softwares, data, telecommunication, people, and procedure to collect, manipulate, store, and process the data into information. Based on a research about the objectives of using IT in prominent education domain in USA, Alavi and Gallupe (2003: 87) found some objectives of using IT: fixing competitive positioning, improving brand image, improving teaching-learning quality, fostering students' satisfaction, increasing income, broadening students' basis, promoting service quality, cutting operational budget, and developing new products and services.

One of the popular softwares as teaching apps creator is flash. Flash is a program designed to create animations of texts and images starting from the simple to the complex ones (Jonathan Gay,2013)[7]. One of popular softwares as animation creator is Adobe Flash. Adobe Flash CS5Professional is among various animation creators. It offers a lot of features and simplicity to use. Its interface display, functions and palet choices are many. There are also a complete set of tools which enables us to create attractive animations (Madcom,2011)[8].

Adobe Flash CS5 Professional-based teaching media was used to to teach Javanase alphabets in this research. This was an attempt to make teaching materials in a real way and easier to understand by eleventh grade students of MAN Kutowinangun in the academic year of 2013/2014

\section{Research Methods}


In research design, the researchers used pseudo experiment (quasi experimental design). The researchers realized that it was impossible to control all relevant variables. The research applied Pretest-Posttest Control Group Design where a goup of subjects were taken from the population. They were given pretest and then consecutive treatments.

The scheme of Pretest-Posttest Control Group Design in this research was described by Sugiyono (2010: 112)[9] as follows:

Table 1. Pretest-Posttest Control Group Design

\begin{tabular}{|l|c|c|c|}
\hline \multicolumn{1}{|c|}{ Group } & Pretest & Treatment & Posttest \\
\hline Experimental & O1 & $\mathrm{X}$ & O2 \\
\hline Control & O3 & - & O4 \\
\hline
\end{tabular}

Cluster Random Samplingwas chosen by the researchers. Each individual in the population has the same chance to be taken as sample members. The samples were the eleventh grade students of MAN Kutowinangun. The instruments in the research were observation and test.

To analyze the data, there were two employed tests: normality test and homogeneity test. Hypotheses testing was then carried out to examine the differences in students' learning outcomes. The hypotheses testing using $\mathrm{T}$-test was given in the pretest and posttest.

\section{Result}

The data description of learning outcomes were gained from pretest and posttest. The pretest of eleventh grade students of IPS 3 (social department) as experimental group showed that the average score of these 31 students was 63.35. The priorskills of experimental group in reading Javanese alphabets covered six aspects. They were: 1) identifying aksara legena and pasangan in Javanese alphabets; 2) identifying aksara sandhangan in texts written in Javanese alphabets; 3) finding out aksara wilangan in Javanese alphabets; 4) finding out aksara murda in Javanese alphabets; 5) finding out aksara rekan in Javanese alphabets; and 6) finding out finding out aksara swara in Javanese alphabets. The description is shown below.

Table 2. Percentage of Pretest Score Skill of Reading Javanese Aphabets in Experimental

\begin{tabular}{|c|c|c|c|c|c|c|}
\hline Category & Aspect 1 & Aspect 2 & Aspect 3 & Aspect 4 & Aspect 5 & Aspect 6 \\
\hline Pretest Score & $73.5 \%$ & $63.2 \%$ & $76.8 \%$ & $47.7 \%$ & $74.8 \%$ & $43.9 \%$ \\
\hline Average Score & \multicolumn{7}{|c|}{$63.3 \%$} \\
\hline
\end{tabular}

The average score of eleventh grade students of IPS 1 as the control group was 63.5. They were as many as 32 students. The prior skill of the control group in reading Javanese alphabets which covered six aspects is displayed below.

Table 3. Percentage of Pretest Score Skill of Reading Javanese Alphabets in Control Group

\begin{tabular}{|c|c|c|c|c|c|c|}
\hline Category & Aspect 1 & Aspect 2 & Aspect 3 & Aspect 4 & Aspect 5 & Aspect 6 \\
\hline Pretest Score & $79.4 \%$ & $66.3 \%$ & $70.6 \%$ & $58.8 \%$ & $65 \%$ & $41.3 \%$ \\
\hline Average Score & \multicolumn{7}{|c|}{$63.5 \%$} \\
\hline
\end{tabular}

The data of posttest was used to investigate the final skill of students after getting the treatments. The experimental group was taught Javanese alphabets using Adobe Flash. Then they were given posttest to see the final score/students' learning outcomes. Based on the posttest result, as many as 31 students in IPS 3 as experimental group had average score 82.065. The final skill of experimental group in reading Javanese alphabets covering six aspects is described in the following table. 
Table 4. Percentage of Posttest Score Skill of Reading Javanese Alphabets in Experimental Group

\begin{tabular}{|c|c|c|c|c|c|c|}
\hline Category & Aspect 1 & Aspect 2 & Aspect 3 & Aspect 4 & Aspect 5 & Aspect 6 \\
\hline Posttest Score & $87.7 \%$ & $74.8 \%$ & $87.1 \%$ & $89 \%$ & $86.5 \%$ & $67.1 \%$ \\
\hline Average Score & \multicolumn{7}{|c|}{$82 \%$} \\
\hline
\end{tabular}

The posttest result of eleventh grade students of IPS 1 as control group with 32 students showed that the average score was 73.563. The final skill of the control group in reading Javanese alphabets covered six aspects of assessment. The result is displayed below.

Table 5. Percentage of Posttest Score Skill of Reading Javanese Alphabets in Control Group

\begin{tabular}{|c|c|c|c|c|c|c|}
\hline Category & Aspect 1 & Aspect 2 & Aspect 3 & Aspect 4 & Aspect 5 & Aspect 6 \\
\hline Posttest Score & $85 \%$ & $60.6 \%$ & $62.5 \%$ & $76.9 \%$ & $96.3 \%$ & $60 \%$ \\
\hline Average Score & \multicolumn{7}{|c|}{$73.5 \%$} \\
\hline
\end{tabular}

\section{Discussion}

\section{T-test of Pretest in Experimental and Control Group}

Based on the normality test and homogeneity test, the data were normally distributed and homogeneous. Thus, the step could be continued to balance testing or similarity test of average score. Two-tailed t-test with SPSS 17.0 for Windowsand Independent Sample T-Test was administered. The significance degree was 0.05 . The proposed hypoyheses were.

$H_{0}$ : In pretest there is no significant difference in skill of reading Javanese alphabets between students using Adobe Flash CS5 Professionaland those who do not use Adobe Flash CS5 Professional.

$H_{a}$ : In pretest there is significant difference in skill of reading Javanese alphabets between students using Adobe Flash CS5 Professionaland those who do not use Adobe Flash CS5 Professional.

If those hypotheses are formulated in statistics, the result is as follows:

$H_{0} \quad: \mu 1=\mu 2$ (there is no difference between the samples)

$H_{a}: \mu 1 \neq \mu 2$ (there is difference between the samples)

Note:

$\mu_{1}=$ experimental group

$\mu_{2}=$ control group

After testing using t-test and obtaining the tcount, then the result was compared to the value of ttable. The value of ttable was obtained from $\mathrm{db}=\mathrm{n} 1+\mathrm{n} 2-2$. The criteria is if the significance is lower than $0.05, \mathrm{H}_{0}$ is rejected and if the significance is higher than $0.05, \mathrm{H}_{0}$ is accepted. After the data analysis was conducted, the display of t-test result of pretest is given below.

Table 5. Result of T-test on Pretest Experimental and Control Group

\begin{tabular}{|l|l|}
\hline Category & $\begin{array}{l}\text { T-test Score on Pretest of } \\
\text { Experimentaland Control Group }\end{array}$ \\
\hline Degree of Freedom (df) & 61 \\
\hline t-count & -0.07 \\
\hline t-table & 1,670 \\
\hline Significance (2-tailed) & 0,945 \\
\hline
\end{tabular}




\begin{tabular}{|l|l|}
\hline Test Result & Ho was accepted \\
\hline Note & There was no difference \\
\hline
\end{tabular}

From the output of Independent Sample T-Test, it was seen that the significance was 0.945. Because the significance was higher than 0.05 it meant that both experimental and control group were balanced. Thus, students who were taught using Adobe Flash 9 (experimental group) and those who were taught using conventional teaching/whiteboard had the same prior skill.

\section{T-test of Posttest in Experimental and Control Group}

After the data from posttest were gained, then the next step was hypotheses testing. One-tailed ttest using SPSS 17.0 for Windows and SPSS 17.0 for Windows.The significance was $\alpha=0,05$. The hypotheses were:

$H_{0}$ : In posttest there is no significant difference in skill of reading Javanese alphabets between students using Adobe Flash CS5 Professionaland those who do not use Adobe Flash CS5 Professional.

$H_{a}$ : In posttest there is significant difference in skill of reading Javanese alphabets between students using Adobe Flash CS5 Professionaland those who do not use Adobe Flash CS5 Professional. If those hypotheses are formulated in statistics, the result is as follows:

$H_{0} \quad: \mu 1=\mu 2$ (there is no difference between the samples)

$H_{a}: \mu 1 \neq \mu 2$ (there is difference between the samples)

Note:

$\mu_{1}=$ experimental group

$\mu_{2}=$ control group

After testing using t-test and obtaining the tcount, then the result was compared to the value of ttable. The value of ttable was obtained from $\mathrm{db}=\mathrm{n} 1+\mathrm{n} 2-2$. The criteria is if the significance is lower than $0.05, \mathrm{H}_{0}$ is rejected and if the significance is higher than $0.05, \mathrm{H}_{0}$ is accepted (Singgih Santoso, 2009: 264). After the data analysis was conducted, the display of t-test result of posttest is given below.

Table 5. Result of T-test on Posttest Experimental and Control Group

\begin{tabular}{|l|l|}
\hline Category & $\begin{array}{l}\text { T-test Score of Posttestof } \\
\text { Experimentaland Control Group }\end{array}$ \\
\hline Degree of Freedom $(\mathrm{df})$ & 61 \\
\hline t-count & 4.359 \\
\hline t-table & 1.670 \\
\hline Test Result & Ha was accepted \\
\hline Note & There was difference \\
\hline
\end{tabular}

In the Independent Sample T-Test above, it was seen that the tcount for posttestequal varians assumed was 4.359 . The value of ttable with $\mathrm{db}=61$ was 1.670 . 
It turned out that tcount was higher than ttable( $4.359>1.670)$. Thus, Ho was rejected and Ha was accepted. This implied that there was significant difference on the learning outcomes in skill of reading Javanese alphabets between students taught using Adobe Flash CS5 Professional and those taught without using Adobe Flash CS5 Professional.

\section{T-test of Pretest and Posttest in Experimental and Control Group}

To examine the increasing score between experimental and control group, the data from pretest and posttest were then tested using hypotheses testing to see the effectiveness. The data were compared. The hypotheses testing used Paired Sample T-Test with the significance degree $\alpha=0.05$. The proposed hypotheses were:

$H_{0}$ : The teaching activity using Adobe Flash CS5 Professionalto teach the skill of reading Javanese alphabets for eleventh grade students is not more effective than the teaching activity without using Adobe Flash CS5 Professional.

$H_{a}$ : The teaching activity using Adobe Flash CS5 Professionalto teach the skill of reading Javanese alphabets for eleventh grade students is more effective than the teaching activity without using Adobe Flash CS5 Professional.

If those hypotheses are formulated in statistics, the result is as follows:

$H_{0}: \mu 1 \leq \mu 2$ (sample 1 is not more effective than sample 2)

$H_{a}: \mu 1>\mu 2$ (sample 1 is more effective than sample 2)

Note:

$\mu_{1}=$ experimental group

$\mu_{2}=$ control group given below.

After the data analysis was conducted, the display of t-test result of pretest and posttest is

Table 6. Result of T-test Pretestand Posttest in Experimental Group

\begin{tabular}{|l|l|}
\hline Category & $\begin{array}{l}\text { T-test Score of Pretestand } \\
\text { Posttest of Experimental Group }\end{array}$ \\
\hline Degree of Freedom (df) & 30 \\
\hline Mean & 18,710 \\
\hline t-count & 11,896 \\
\hline
\end{tabular}

Table 7. Result of T-test Pretest and Posttest in Control Group

\begin{tabular}{|l|l|}
\hline Category & $\begin{array}{l}\text { T-test Score of Pretestand } \\
\text { Posttest of Control Group }\end{array}$ \\
\hline DerajatKebebasan (df) & 31 \\
\hline Mean & 10,063 \\
\hline t-hitung & 9,454 \\
\hline
\end{tabular}

From the result of Paired Sample T-Test above, it could be concluded that there was increasing score (tcount) in experimental group. The posttest-pretest score was 11.896. Meanwhile, there was also increasing score (tcount) in control group. The posttest-pretest score in control group was 9.454. This confirmed that the increasing score of experimental group was higher than that of control group. 
Ho stating that the use of Adobe Flash CS5 Professional to teach skill in reading Javanese alphabets for eleventh grade students is not more effective than the use of conventional media was rejected. In the contrary, Ha stating that the use of Adobe Flash CS5 Professional to teach skill in reading Javanese alphabets for eleventh grade students is more effective than the use of conventional media was accepted.

\section{Conclusion}

Teaching students to read Javanese alphabets using Adobe Flash CS5 Professional was proved more effective compared to teaching students without Adobe Flash CS5 Professional. The increasing score (tcount) of experimental group (eleventh grade students of IPS 3) was higher than the increasing score (tcount) of control group (eleventh grade students of IPS 3). The result was 11,896 > 9,454.

By considering the finding of this research, it is strongly recommended for teachers to make use of IT-based teaching media in teaching the students. There are many promising benefits if they do so. Students will be actively engaged to the materials, they will not feel bored because their learning motivation will grow, and the teaching activities will vary. This, in turn, enables teachers to reach the teaching objectives that is to generate better learning outcomes.

\section{References}

[1] Sudaryanto, Tata Bahasa Baku BahasaJawa. Yogyakarta: Duta Wacana University Press, 1991.

[2] H. . Tarigan, MenulisSebagaiSuatuKeterampilanBerbahasa. Bandung: Angkasa, 2008.

[3] A. Arsyad, Media Pembelajaran. Jakarta: Raja GrafindoPersada, 2013.

[4] Trianto, Mendesain Model PembelajaranInovatif-Progresif. Jakarta: Kencana, 2010.

[5] O. Hamalik, Media Pendidikan. Bandung: Citra AdityaBakti, 1985.

[6] G. R. Ralph Stair, Fundamentals of Informasi System-Cengage Learning. Canada: Nelson Educatioun, 2011.

[7] Jonathan Gay, The History Of Flash. 2013.

[8] Madcoms, KupasTuntasLengkap Adobe Flash Professional CS5. Yogyakarta: Andi Offset, 2011.

[9] Sugiyono, Pendekatankuantitatif, kualitatifdanpengembangan. Bandung: Alfabeta, 2010. 